\title{
EFEKTIFITAS BAKTERI ENDOFIT DAN PENAMBAHAN INDOLE ACETIC ACID (IAA) DALAM MENINGKATKAN PERTUMBUHAN TANAMAN PADI Oryza sativa L.
}

\author{
ARIA RIZKi RAMADHAN, OEDJIJONO, RATIH DEWI HASTUTI
}

Fakultas Biologi, Universitas Jenderal Soedirman, Jalan dr. Suparno 63 Purwo kerto 53122

\begin{abstract}
A B S T R A C T
Rice plant needs essential and non-essential nutrients to grow. However, the use of inorganic fertilizers may affect the soil microbe community which expected to increase the availability of nutrients for both plants and microbes, a condition that could control several types of diseases. Many efforts were made to find alternative fertilizer which environmentally friendly, for instance by exploiting microorganisms such as endophytic bacteria associated with plant tissue or seed plant cell. This research aimed to determine the effect of endophytic bacteria, the concentration of IAA, and the combination of endophytic bacteria with a concentration of IAA, on the growth of rice plant. This research was conducted at the Laboratory of Soil Biology, The Soil Research Institute located in Cimanggu Bogor from December 2015 to February 2016. This research was a Completely Randomized Design (CRD) with two factors, i.e., the inoculant of endophytic bacteria (2.2 KT, KR 6 , and I CM), and the concentration of IAA $(0,0.01,0.1,0.5$, and $1 \mathrm{ppm})$. Three replicates were applied for each treatment of the inoculant combined with different doses of IAA. The variety of rice plants tested were Inpari 13 and IR 64 . The potential test has been applied to determine the factor with the highest yield of the rice plant growth. The parameters observed were the height of the rice plant, the length of the rice plant roots, and the total weight of the plant including root. The results showed the inocula of endophytic bacteria alone had no effect to increase growth for both IR 64 and Inpari 13 rice variety. The IAA concentration of $0.1 \mathrm{ppm}$ was able to increase the height of rice plant and the length of rice plant root for both IR 64 rice plant and Inpari 13. The combined treatment of KR 6 bacterial inoculum with $1 \mathrm{ppm}$ of IAA concentration was effectively promoted rice plant growth for both IR 64 and Inpari 13.
\end{abstract}

KEY WORDS: plant growth promoting bacteria, IAA, rice plants

Penulis korespondensi: ARIA RIZKI RAMADHAN | email: aramadh3@gmail.com

\section{PEND A H UL U A N}

Keragaman mikroorganisme di alam sangat melimpah dan berperan penting bagi kehidupan manusia, termasuk dalam bidang pertanian. Mikroorganisme terbagi atas mikroorganisme non-simbiotik yang ditemukan bebas di alam dan mikroorganisme simbiotik yang berinteraksi dengan tanaman, contohnya adalah mikroorganisme endofit.

Bakteri endofit merupakan bakteri saprofit yang hidup dan berasosiasi dengan jaringan tanaman sehat tanpa menimbulkan gejala penyakit (Hallmann et al., 1997; Backman \& Sikora, 2008). Beberapa bakteri endofit dapat menghasilkan hormon perangsang pertumbuhan tanaman, salah satunya adalah IAA (Indole Acetic Acid) atau dikenal dengan auksin. Auksin berperan memacu pertumbuhan tanaman dan biasanya ditemukan pada jaringan meristem (Spaepen et al., 2007). Bakteri endofit selain berperan dalam peningkatan pertumbuhan tanaman, juga mampu memobilisasi fosfat dan berperan sebagai pengendali hayati (Hallmann, 2001). Bakteri endofit dapat diisolasi dari beberapa tanaman berpembuluh, salah satunya adalah tanaman padi (Oryza sativa L.).

Penggunaan pupuk kimia yang berlebihan dan terus-menerus perlu ditinjau kembali, karena selain tidak efisien juga dapat mengakibatkan dampak negatif terhadap lingkungan. Upaya mengurangi pencemaran lingkungan di lahan pertanian yang disebabkan oleh penggunaan pupuk kimia berlebihan, salah satunya dilakukan dengan penggunaan pupuk biologi yaitu dengan memanfaatkan penggunaan mikroorganisme dari alam, seperti bakteri endofit.
Penelitian ini bertujuan untuk mengetahui efektivitas bakteri endofit terhadap peningkatan pertumbuhan padi, mengetahui efektivitas konsentrasi IAA terhadap peningkatan pertumbuhan padi, dan mengetahui efektivitas kombinasi bakteri endofit dan IAA terhadap peningkatan pertumbuhan padi.

\section{METODE PENELITIAN}

Penelitian dilaksanakan di Laboratorium Biologi Tanah, Balai Penelitian Tanah, Cimanggu, Bogor, dari bulan Desember 2015 sampai dengan Februari 2016. Bahan-bahan yang digunakan yaitu biji padi varietas Inpari 13 dan IR 64, bakteri endofit hasil skrining, medium Pikovskaya agar, medium King's B agar, medium Azotobacter agar, medium Okon agar untuk Azospirillum, medium pelarut kalium agar, medium N-Free agar, medium LB + tryptophan, reagen Salkowski, larutan stok IAA, larutan hara, wrapper, tissue, dan kapas.. Peralatan yang digunakan yaitu cawan Petri, tabung reaksi, labu Erlenmeyer, jarum Osche, pipet tetes, pipet ukur, neraca analitik, hot plate and stirrer, Laminar Air Flow (LAF), autoklaf, oven, shaker orbital, rak tabung, spektrofotometer, sentrifus, tabung sentrifus, mikropipet dan tip, object glass, cover glass, mikroskop, plastik pouches, dan rak pouches..

Rancangan dalam uji in-planta adalah Rancangan Acak Lengkap (RAL) dengan dua faktor, yaitu inokulan bakteri endofit selektif (KT 2.2, KR 6, dan I CM) dan konsentrasi IAA $(0,0.01,0.1,0.5$, dan 1 ppm). Inokulan bakteri dikombinasikan dengan dosis IAA yang berbeda, masingmasing perlakuan diulang tiga kali. Tanaman padi yang diuji adalah varietas Inpari 13 dan IR 64. Parameter yang diamati adalah tinggi tanaman, panjang akar, berat tanaman total dan berat akar. Hasil pengamatan dianalisis menggunakan uji ANOVA dengan tingkat kesalahan 5\%. Data yang menunjukkan hasil berbeda nyata dilanjutkan dengan uji BNT (Beda Nyata Terkecil). 


\section{HASIL DAN PEMBAHASAN}

Bakteri isolat I CM berpengaruh paling baik terhadap tinggi tanaman padi varietas Inpari 13 (Tabel 1). Bakteri endofit I CM mampu menambat nitrogen untuk meningkatkan pertumbuhan tanaman, khususnya peningkatan tinggi tanaman yang sangat dipengaruhi oleh ketersediaan unsur N (Ismunadji \& Dijkshoorn, 1971).

Isolat bakteri endofit sebaliknya berpengaruh kurang baik terhadap tinggi tanaman padi varietas IR 64. Tinggi tanaman IR 64 yang paling baik tanpa perlakuan pemberian bakteri endofit diduga karena kondisi celah antar ruang pouches yang tidak selalu dalam keadaan terbuka, sehingga menyebabkan distribusi larutan hara tidak merata pada setiap ruang pouches, sehingga penyerapan unsur hara oleh tanaman pun menjadi tidak merata.

Tanaman padi varietas IR 64 mengeluarkan eksudat akar yang diduga komposisinya menghambat pertumbuhan dan perkembangan bakteri endofit uji, sehingga nutrisi berupa larutan hara tidak dapat disintesis dan ditransfer ke dalam jaringan tanaman, yang mempengaruhi rendahnya tinggi tanaman.

Perlakuan penambahan IAA dengan konsentrasi 0,1 ppm berpengaruh meningkatkan rata-rata tinggi tanaman padi varietas IR 64 sebesar 3,31 cm (Tabel 2). Penambahan IAA sebaliknya tidak berbeda nyata untuk meningkatkan panjang akar tanaman padi varietas Inpari 13. Penelitian Maftuchah et al. (2000) menunjukkan bahwa konsentrasi IAA 0,1 ppm memberikan persentase pertumbuhan tunas tertinggi pada kalus padi Cisadane sebesar 26,7\%. Penelitian Dewi (2008) menunjukkan bahwa kecambah yang diberi perlakuan IAA 0,1 ppm menunjukkan pertambahan tinggi yang lebih besar dari tanaman kontrol.

Perlakuan penambahan IAA 1 ppm tanpa bakteri endofit tidak berbeda nyata dengan kombinasi bakteri KR 6 + IAA 1 ppm, namun berpengaruh nyata dalam meningkatkan tinggi tanaman padi varietas IR 64, dengan tinggi rata-rata 4,11 cm. Kombinasi bakteri I $\mathrm{CM}+$ IAA 0,5 ppm tidak berbeda nyata dengan kombinasi bakteri I CM + IAA 1 ppm, namun berpengaruh paling baik meningkatkan tinggi tanaman sebesar 4,19 $\mathrm{cm}$ (Tabel 3). Tinggi tanaman padi IR 64 yang berpengaruh paling baik disebabkan karena IAA dikombinasikan dengan isolat bakteri yang tidak berpengaruh meningkatkan tinggi tanaman padi varietas IR 64 (Tabel 1).

Perlakuan penambahan bakteri endofit tidak berpengaruh nyata terhadap panjang akar tanaman padi varietas Inpari 13 maupun IR 64 (Tabel 4). Hal ini diduga karena bakteri endofit memiliki interaksi yang buruk terhadap tanaman inangnya, terutama kolonisasi bakteri endofit pada akar. Hal ini diduga karena bakteri endofit memiliki interaksi yang buruk dan tidak seimbang terhadap tanaman inangnya, terutama kolonisasi bakteri endofit pada akar. Eksudat yang dihasilkan tanaman dengan komposisi berbeda-beda mampu meningkatkan perkembangan mikroba tertentu dan menghambat perkembangan mikroba lainnya (Husein et al., 2008).

Tabel 1. Rerata tinggi tanaman padi yang diinokulasi dengan isolat bakteri endofit

\begin{tabular}{lll}
\hline \multirow{2}{*}{ Perlakuan } & \multicolumn{2}{l}{ Tinggi Tanaman (cm) } \\
\cline { 2 - 3 } & IR 64 & Inpari 13 \\
\hline Kontrol & $3,94 \mathrm{a}$ & $3,48 \mathrm{~b}$ \\
KT 2.2 & $2,67 \mathrm{~b}$ & $3,70 \mathrm{ab}$ \\
KR 6 & $2,19 \mathrm{c}$ & $3,66 \mathrm{ab}$ \\
I CM & $1,51 \mathrm{~d}$ & $3,87 \mathrm{a}$ \\
\hline \multicolumn{2}{l}{ Keterangan: Angka yang diikuti dengan huruf yang sama dalam satu }
\end{tabular}

Keterangan: Angka yang diikuti dengan huruf yang sama dalam satu kolom tidak berbeda nyata pada uji BNT pada tingkat kesalahan 5\%

Tabel 2. Rerata tinggi tanaman padi yang diinokulasi dengan IAA

\begin{tabular}{lll}
\hline \multirow{2}{*}{ Perlakuan } & \multicolumn{2}{l}{ Tinggi Tanaman (cm) } \\
\cline { 2 - 3 } & IR 64 & Inpari 13 \\
\hline $0 \mathrm{ppm}$ & $2,31 \mathrm{~b}$ & $3,26 \mathrm{~b}$ \\
$0.01 \mathrm{ppm}$ & $2,30 \mathrm{~b}$ & $3,81 \mathrm{a}$ \\
$0.1 \mathrm{ppm}$ & $3,31 \mathrm{a}$ & $3,80 \mathrm{a}$ \\
$0.5 \mathrm{ppm}$ & $2,56 \mathrm{~b}$ & $3,77 \mathrm{a}$ \\
$1 \mathrm{ppm}$ & $2,39 \mathrm{~b}$ & $3,76 \mathrm{a}$ \\
\hline
\end{tabular}

Keterangan: Angka yang diikuti dengan huruf yang sama dalam satu kolom tidak berbeda nyata berdasarkan uji BNT pada tingkat kesalahan $5 \%$

Tabel 3. Rerata tinggi tanaman padi yang diinokulasi dengan kombinasi bakteri endofit dan IAA

\begin{tabular}{lll}
\hline \multirow{2}{*}{ Perlakuan } & \multicolumn{2}{l}{ Tinggi Tanaman (cm) } \\
\cline { 2 - 3 } & IR 64 & Inpari 13 \\
\hline IAA 0 ppm & $3,70 \mathrm{~b}$ & $2,51 \mathrm{f}$ \\
IAA 0,01 ppm & $3,97 \mathrm{ab}$ & $3,85 \mathrm{bc}$ \\
IAA 0,1 ppm & $3,97 \mathrm{ab}$ & $3,80 \mathrm{bcd}$ \\
IAA 0,5 ppm & $3,94 \mathrm{ab}$ & $3,62 \mathrm{~cd}$ \\
IAA 1 ppm & $4,11 \mathrm{a}$ & $3,62 \mathrm{~cd}$ \\
KT 2.2 + IAA 0 ppm & $3,19 \mathrm{c}$ & $3,65 \mathrm{~cd}$ \\
KT 2.2 + IAA 0,01 ppm & $3,83 \mathrm{ab}$ & $3,75 \mathrm{bcd}$ \\
KT 2.2 + IAA 0,1 ppm & $3,88 \mathrm{ab}$ & $3,81 \mathrm{bcd}$ \\
KT 2.2 + IAA 0 & $1,76 \mathrm{~d}$ & $3,57 \mathrm{~d}$ \\
KT 2.2 + IAA 1 ppm & $0,71 \mathrm{e}$ & $3,74 \mathrm{bcd}$ \\
KR 6 + IAA 0 ppm & $1,63 \mathrm{~d}$ & $3,63 \mathrm{~cd}$ \\
KR 6 + IAA 0,01 ppm & $0,71 \mathrm{e}$ & $3,82 \mathrm{bcd}$ \\
KR 6 + IAA 0,1 ppm & $3,83 \mathrm{ab}$ & $3,62 \mathrm{~cd}$ \\
KR 6 + IAA 0,5 ppm & $0,71 \mathrm{e}$ & $3,70 \mathrm{bcd}$ \\
KR 6 + IAA 1 ppm & $4,05 \mathrm{a}$ & $3,55 \mathrm{~d}$ \\
I CM + IAA 0 ppm & $0,71 \mathrm{e}$ & $3,24 \mathrm{e}$ \\
I CM + IAA 0,01 ppm & $0,71 \mathrm{e}$ & $3,80 \mathrm{bcd}$ \\
I CM + IAA 0,1 ppm & $1,58 \mathrm{~d}$ & $3,96 \mathrm{ab}$ \\
I CM + IAA 0,5 ppm & $3,84 \mathrm{ab}$ & $4,19 \mathrm{a}$ \\
I CM + IAA 1 ppm & $0,71 \mathrm{e}$ & $4,15 \mathrm{a}$ \\
\hline
\end{tabular}

Keterangan : Angka yang diikuti dengan huruf yang sama dalam satu kolom tidak berbeda nyata berdasarkan uji BNT pada tingkat kesalahan 5\%

Penambahan konsentrasi IAA 0.1 ppm berpengaruh meningkatkan panjang akar tanaman padi varietas IR 64, dengan panjang rata-rata $3,38 \mathrm{~cm}$ (Tabel 14). Penambahan IAA sebaliknya memberikan pengaruh yang tidak berbeda nyata pada peningkatan panjang akar tanaman padi varietas Inpari 13. Hal ini menunjukkan bahwa konsentrasi yang diberikan tepat dan optimal bagi pertumbuhan tanaman padi, karena berada pada konsentrasi yang optimal di antara batas rentang konsentrasi IAA. Konsentrasi IAA 0,1 ppm menghasilkan nilai rata-rata inisiasi akar tercepat (Munarti \& Kurniasih, 2014). 
Tabel 4. Rerata panjang akar tanaman padi IR 64 yang diinokulasi dengan isolat bakteri endofit

\begin{tabular}{ll}
\hline Perlakuan & Panjang Akar $\mathbf{( c m )}$ \\
\cline { 2 - 2 } & IR 64 \\
\hline Kontrol & $3,21 \mathrm{a}$ \\
KT 2.2 & $2,95 \mathrm{~b}$ \\
KR 6 & $2,88 \mathrm{~b}$ \\
I CM & $1,70 \mathrm{c}$ \\
\hline
\end{tabular}

Keterangan: Angka yang diikuti dengan huruf yang sama dalam satu kolom tidak berbeda nyata berdasarkan uji BNT pada tingkat kesalahan 5\%

Tabel 5. Rerata panjang akar tanaman padi yang diinokulasi dengan IAA

\begin{tabular}{lll}
\hline \multirow{2}{*}{ Perlakuan } & \multicolumn{2}{l}{ Panjang Akar (cm) } \\
\cline { 2 - 3 } & IR 64 & Inpari 13 \\
\hline $0 \mathrm{ppm}$ & $2,50 \mathrm{bc}$ & $2,71 \mathrm{~b}$ \\
$0.01 \mathrm{ppm}$ & $2,26 \mathrm{c}$ & $3,27 \mathrm{a}$ \\
$0.1 \mathrm{ppm}$ & $3,38 \mathrm{a}$ & $3,20 \mathrm{a}$ \\
$0.5 \mathrm{ppm}$ & $2,76 \mathrm{~b}$ & $3,28 \mathrm{a}$ \\
$1 \mathrm{ppm}$ & $2,53 \mathrm{~b}$ & $3,24 \mathrm{a}$ \\
\hline
\end{tabular}

Keterangan : Angka yang diikuti dengan huruf yang sama dalam satu kolom tidak berbeda nyata berdasarkan uji BNT pada tingkat kesalahan $5 \%$

Tabel 6. Rerata panjang akar tanaman padi yang diinokulasi dengan kombinasi bakteri endofit dan IAA

\begin{tabular}{lll}
\hline \multirow{2}{*}{ Perlakuan } & \multicolumn{2}{l}{ Panjang Akar (cm) } \\
\cline { 2 - 3 } & IR 64 & Inpari 13 \\
\hline IAA 0 ppm & 3,24 abcd & $2,13 \mathrm{~d}$ \\
IAA 0,01 ppm & $3,32 \mathrm{abc}$ & $3,42 \mathrm{ab}$ \\
IAA 0,1 ppm & $3,15 \mathrm{bcde}$ & $3,28 \mathrm{abc}$ \\
IAA 0,5 ppm & $3,04 \mathrm{cde}$ & $3,26 \mathrm{abc}$ \\
IAA 1 ppm & 3,27 abcd & $3,04 \mathrm{bc}$ \\
KT 2.2 + IAA 0 ppm & $3,12 \mathrm{bcde}$ & $3,05 \mathrm{bc}$ \\
KT 2.2 + IAA 0,01 ppm & $2,86 \mathrm{def}$ & $3,22 \mathrm{abc}$ \\
KT 2.2 + IAA 0,1 ppm & 3,19 abcde & $3,40 \mathrm{ab}$ \\
KT 2.2 + IAA 0,5 ppm & 2,75 ef & $3,02 \mathrm{bc}$ \\
KT 2.2 + IAA 1 ppm & 2,48 fg & $3,38 \mathrm{ab}$ \\
KR 6 + IAA 0 ppm & $2,91 \mathrm{cdef}$ & $2,83 \mathrm{c}$ \\
KR 6 + IAA 0,01 ppm & $2,15 \mathrm{~g}$ & $3,33 \mathrm{ab}$ \\
KR 6 + IAA 0,1 ppm & 3,54 ab & $3,02 \mathrm{bv}$ \\
KR 6 + IAA 0,5 ppm & 2,50 fg & $3,55 \mathrm{a}$ \\
KR 6 + IAA 1 ppm & $3,65 \mathrm{a}$ & $3,57 \mathrm{a}$ \\
I CM + IAA 0 ppm & $0,71 \mathrm{~h}$ & $2,84 \mathrm{c}$ \\
I CM + IAA 0,01 ppm & $0,71 \mathrm{~h}$ & $3,10 \mathrm{abc}$ \\
I CM + IAA 0,1 ppm & $3,62 \mathrm{a}$ & $3,10 \mathrm{abc}$ \\
I CM + IAA 0,5 ppm & 2,76 ef & $3,29 \mathrm{abc}$ \\
I CM + IAA 1 ppm & $0,71 \mathrm{~h}$ & $2,97 \mathrm{bc}$ \\
\hline Keterangan: Angka yang diikuti dengan huruf yang sama dalam satu \\
kolom tidak berbeda nyata berdasarkan uji BNT pada tingkat \\
kesalahan 5\% & &
\end{tabular}

Kombinasi bakteri KR 6 + IAA 1 ppm berpengaruh meningkatkan panjang akar tanaman padi varietas IR 64 maupun Inpari 13 (Tabel 6). Bakteri endofit isolat KR 6 menghasilkan fitohormon IAA sebesar 9,958 ppm. Akar merupakan salah satu organ tanaman yang sangat sensitif terhadap konsentrasi IAA. IAA 1 ppm merangsang pertumbuhan akar tanaman padi dengan mekanisme pemanjangan akar utama, pembentukan akar lateral dan akar adventif, sehingga mempengaruhi volume akar tersebut.

Bakteri endofit bergabung dengan beberapa proses fisiologi tanaman dengan cara memasukkan IAA yang dihasilkannya ke tanaman, yang menjadikan tanaman lebih sensitif dalam mengubah konsentrasi IAA endogen sehingga membantu dalam pembentukkan akar lateral dan akar adventif serta elongasi akar primer (Leveau \& Lindow, 2005).

Perlakuan tanpa penambahan bakteri endofit berpengaruh menambah berat tanaman padi varietas IR 64 sebesar 0,82 gram (Tabel 7). Hal ini diduga karena terjadi kompetisi nutrisi antara tanaman padi dengan mikroba pada awal interaksi (Sylvia et al., 2005). Eksudat akar juga menjadi faktor yang dapat meningkatkan atau menghambat pertumbuhan dan perkembangan bakteri (Husein et al., 2008).

Tabel 7. Rerata berat tanaman total padi IR 64 yang diinokulasi dengan isolat bakteri endofit

\begin{tabular}{ll}
\hline Perlakuan & Berat Tanaman Total (gram) \\
\cline { 2 - 2 } Kontrol & $0,82 \mathrm{a}$ \\
KT 2.2 & $0,80 \mathrm{~b}$ \\
KR 6 & $0,79 \mathrm{c}$ \\
I CM & $0,73 \mathrm{~d}$ \\
\hline
\end{tabular}

Keterangan: Angka yang diikuti dengan huruf yang sama dalam satu kolom tidak berbeda nyata berdasarkan uji BNT pada tingkat kesalahan $5 \%$

Tabel 8. Rerata berat tanaman padi varietas IR 64 yang diinokulasi dengan kombinasi bakteri endofit dan IAA

\begin{tabular}{ll}
\hline Perlakuan & Berat Tanaman Total (gram) \\
\cline { 2 - 2 } & IR 64 \\
\hline IAA 0 ppm & $0,85 \mathrm{a}$ \\
IAA 0,01 ppm & $0,84 \mathrm{a}$ \\
IAA 0,1 ppm & $0,79 \mathrm{f}$ \\
IAA 0,5 ppm & $0,82 \mathrm{~cd}$ \\
IAA 1 ppm & $0,80 \mathrm{e}$ \\
KT 2.2 + IAA 0 ppm & $0,85 \mathrm{a}$ \\
KT 2.2 + IAA 0,01 ppm & $0,79 \mathrm{f}$ \\
KT 2.2 + IAA 0,1 ppm & $0,82 \mathrm{bc}$ \\
KT 2.2 + IAA 0,5 ppm & $0,77 \mathrm{hi}$ \\
KT 2.2 + IAA 1 ppm & $0,78 \mathrm{~g}$ \\
KR 6 + IAA 0 ppm & $0,81 \mathrm{de}$ \\
KR 6 + IAA 0,01 ppm & $0,77 \mathrm{gh}$ \\
KR 6 + IAA 0,1 ppm & $0,78 \mathrm{~g}$ \\
KR 6 + IAA 0,5 ppm & $0,76 \mathrm{i}$ \\
KR 6 + IAA 1 ppm & $0,83 \mathrm{~b}$ \\
I CM + IAA 0 ppm & $0,71 \mathrm{k}$ \\
I CM + IAA 0,01 ppm & $0,71 \mathrm{k}$ \\
I CM + IAA 0,1 ppm & $0,78 \mathrm{gh}$ \\
I CM + IAA 0,5 ppm & $0,75 \mathrm{j}$ \\
I CM + IAA 1 ppm & $0,71 \mathrm{k}$ \\
\hline
\end{tabular}

Keterangan: Angka yang diikuti dengan huruf yang sama dalam satu kolom tidak berbeda nyata berdasarkan uji BNT pada tingkat kesalahan $5 \%$

Ketersediaan hara saat pertumbuhan tanaman mengakibatkan fotosintesis berjalan lebih aktif (Sarief, 1986). Proses pemanjangan, pembelahan dan diferensiasi sel akan terjadi lebih baik sehingga dapat mendukung pertumbuhan tanaman. Penambahan bobot segar dipengaruhi oleh ketersedian unsur hara yang cukup dan seimbang karena aktifitas pembelahan sel meningkat (Goldsworthy \& Fisher, 1996).

Berat tanaman padi varietas IR 64 paling tinggi ditunjukkan oleh perlakuan kontrol, IAA 0,01 ppm tanpa bakteri, dan bakteri KT 2.2 tanpa IAA, dengan 
berat tanaman masing-masing sebesar 0,85, 0,84, dan 0,85 gram (Tabel 8). Isolat bakteri endofit KT 2.2 memiliki kemampuan yang tinggi dalam melarutkan fosfat dan menambat nitrogen, namun IAA yang dihasilkan tidak terlalu tinggi. Konsentrasi IAA 0,01 ppm berpengaruh meningkatkan berat tanaman padi varietas IR 64. Hal tersebut diduga karena adanya triptofan yang dihasilkan eksudat akar. Kadar triptofan yang dihasilkan pada sistem perakaran tanaman padi sebesar 8,3-390 ng per hari (Lugtenberg et al., 1999).

Perlakuan kombinasi bakteri endofit dan IAA tidak berpengaruh nyata terhadap peningkatan berat tanaman padi varietas Inpari 13 disebabkan karena kondisi air yang tersedia bagi tanaman, sehingga mampu melarutkan unsur hara secara optimal. Proses metabolisme pada tubuh tanaman pun akan meningkat, termasuk fotosintesis. Semakin tinggi laju fotosintesis, fotosintat yang dihasilkan semakin banyak, sehingga berat tanaman pun meningkat.

Bakteri endofit meningkatkan berat tanaman disebabkan oleh penghasilan IAA di daerah perakaran. Eksudat akar mengandung triptofan atau senyawa serupa yang dapat digunakan oleh mikroorganisme tanah untuk memproduksi IAA (Singh \& Subba-Rao, 1979). Bakteri endofit penghasil IAA memberikan pengaruh positif terhadap benih padi, sehingga kecambah padi memiliki kemampuan sekresi IAA lebih tinggi dan lebih sensitif (Lestari et al., 2007). IAA akan menyebabkan pektin larut dan dinding sel menjadi lunak sehingga dapat meningkatkan penyerapan air dan sel akan mengembang (George \& Sherington, 1984).

Tabel 9 menunjukkan bahwa berat akar tanaman padi varietas IR 64 yang paling tinggi ditunjukkan oleh perlakuan tanpa penambahan bakteri sebesar 0,78 gram, sebaliknya perlakuan bakteri endofit tidak berpengaruh nyata terhadap berat akar tanaman padi varietas Inpari 13. Berat akar tanaman padi yang tinggi pada perlakuan tanpa penambahan bakteri endofit diduga karena adanya peningkatan pengambilan air oleh sel tanaman (Spaepen et al., 2007). Panjang akar juga berpengaruh terhadap penyerapan air dan hara dari lingkungan sehingga mempengaruhi berat akar. Tanaman dengan volume akar yang besar mampu mengabsorbsi air lebih banyak sehingga mampu bertahan pada kondisi kekurangan air (Palupi \& Dedywiryanto, 2008).

Perlakuan penambahan IAA dan kombinasi bakteri endofit dengan IAA tidak berpengaruh nyata dalam meningkatkan berat akar padi varietas IR 64 maupun Inpari 13. Peningkatan berat segar adalah akibat serapan air dalam jumlah yang besar di sel-sel tanaman dan juga didominasi oleh peningkatan laju fotosintesis, yang akan meningkatkan laju pembentukan karbohidrat dan cadangan makanan. Cadangan makanan tersebut akan membantu penambahan organ-organ tanaman terutama tunas, akar dan daun sehingga akan meningkatkan berat tanaman. Serapan air yang meningkat juga mempengaruhi kelarutan IAA dan volume sel bakteri, sehingga bakteri endofit kurang optimal dalam merangsang peningkatan volume akar (Prawiranata et al., 1988).

Tabel 9. Rerata berat akar tanaman padi IR 64 yang diinokulasi bakteri endofit

\begin{tabular}{ll}
\hline \multirow{2}{*}{ Perlakuan } & Berat Akar (gram) \\
\cline { 2 - 2 } & IR 64 \\
\hline Kontrol & $0,78 \mathrm{a}$ \\
KT 2.2 & $0,76 \mathrm{ab}$ \\
KR 6 & $0,76 \mathrm{ab}$ \\
I CM & $0,72 \mathrm{~b}$ \\
\hline
\end{tabular}

Keterangan: Angka yang diikuti dengan huruf yang sama dalam satu kolom tidak berbeda nyata berdasarkan uji BNT pada tingkat kesalahan $5 \%$

Hasil penelitian menunjukkan bahwa secara keseluruhan, perlakuan inokulasi bakteri endofit tidak berpengaruh meningkatkan pertumbuhan tanaman padi, walaupun berpengaruh pada tinggi tanaman padi varietas Inpari 13 . Hal ini diduga dipengaruhi oleh faktor kandungan air dan nutrisi pada medium percobaan. Pemberian air dan hara dilakukan seimbang untuk menghindari penumpukkan hara yang akan menjadi racun bagi tanaman, namun kondisi batas antar ruang pouches menyebabkan air dan hara hanya terdistribusi sebagian, atau bahkan tidak terdistribusi sama sekali. Hal ini menyebabkan tanaman tidak dapat tumbuh sempurna pada kondisi kekurangan air, sebaliknya tanaman dapat membusuk pada kondisi air yang berlebih. Pemberian air dan hara pada medium pertumbuhan pouches harus diikuti dengan pemeriksaan celah antar ruang pouches. Hal ini dilakukan agar air dan hara dapat terdistribusi merata ke tanaman padi.

\section{KES I M P ULAN DAN SARAN}

Ketiga isolat bakteri endofit uji, yakni KT 2.2, KR 6, dan I CM tidak efektif meningkatkan pertumbuhan tanaman padi varietas IR 64 maupun Inpari 13. Konsentrasi IAA 0,1 ppm efektif meningkatkan pertumbuhan tanaman padi varietas IR 64 maupun Inpari 13. Kombinasi bakteri KR 6 + IAA 1 ppm efektif meningkatkan pertumbuhan tanaman padi varietas IR 64 maupun Inpari 13.

Aplikasi bakteri endofit dan IAA untuk pertumbuhan tanaman padi perlu dilakukan pada medium lainnya seperti medium tanah, dengan waktu aplikasi yang tepat. Bakteri endofit yang digunakan perlu diidentifikasi, agar diketahui dengan pasti karakteristik bakteri sekaligus respon yang dihasilkan terhadap tanaman padi.

\section{AF T AR REFERENSI}

Backman PA, Sikora RA. 2008. Endophytes: An emerging tool for biological control. Biol. Control. 46(1): 1-3.

Dewi IR. 2008. Peranan dan fungsi fitohormon bagi pertumbuhan tanaman [skripsi]. Bandung: Universitas Padjajaran.

Fuchs HWM. 1986. Root regeneration of rose plants as influenced by applied auxins. Acta Horticulture. 189: 101-107.

George EF, Sherington PD. 1984. Plant propagation by tissue culture, Handbook and Directory of Comercial Laboratories. England: Exegetics Ltd. 
Goldsworthy RP, Fisher NM. 1996. Fisiologi tanaman budidaya tropik. Yogyakarta: Universitas Gadjah Mada.

Hallmann J, Quadt-Hallmann A, Mahaffee WF, Kloepper JW. 1997. Bacterial endophytes in agricultural crops. Can. J. Microbiol. 43(10): 895-914.

Hallmann J. 2001. Plant interaction with endophytic bacteria. In: Jeger, M. J., Spence, N. J. (ed). Biotic Interaction in Plant-Pathogen Associations. CAB International p 87-119.

Haryadi SS, Yahya S. 1988. Fisiologi stres lingkungan. Bogor: PAU Bioteknologi IPB.

Hendriyani IS, Setiari N. 2009. Kandungan klorofil dan pertumbuhan kacang panjang (Vigna sinensis) pada tingkat penyediaan air yang berbeda. J. Sains \& Mat. 17(3): 145-150.

Husein E, Saraswati R, Hastuti RD. 2008. Rizobakteri pemacu tumbuh tanaman. Dalam buku: Metode analisis biologi tanah. Bogor: Balai Besar Penelitian dan Pengembangan Sumberdaya Lahan Pertanian. p 191-209

Ismunadji M, Dijkshoorn W. 1971. Nitrogen nutrition of rice plants measured by growth and nutrient content in pot experiment. I. Ionic balance and selective uptake. J Agr Sci. 19:223-236.

Lestari P, Susilowati DN, Riyanti EI. 2007. Pengaruh hormon asam indol asetat yang dihasilkan Azospirillum sp. terhadap perkembangan akar padi. Jurnal AgroBiogen. 3(2): 66-72.

Leveau JHJ, Lindow SE. 2005. Utilization of plant hormone indole-3acetic acid for growth by Pseudomonas putida strain 1290. Appl Environ Microbiol. 71(5): 2365-2371.

Lugtenberg BJJ, Kravchenko LV, Simons M. 1999. Tomato seeds and root exudates sugars: composition, utilization by Pseudomonas biocontrol strains and role in rhizosphere colonization. Environ.Microbiol. 1:439-445.
Maftuchah, Slamet-Loedin IH, Aswidinnor SH. 2000. Induksi tunas dari kalus embriogenik padi Cisadane dalam berbagai konsentrasi IAA dan BAP. Prosiding Seminar Nasional Bioteknologi Pertanian; 7-9 November 2000; Yogyakarta. Yogyakarta: Perhimpunan Bioteknologi Pertanian Indonesia; p.134-140.

Munarti, Kurniasih S. 2014. Pengaruh konsentrasi IAA dan BAP terhadap pertumbuhan stek mikro kentang secara in vitro. Jurnal Pendidikan Biologi, FKIP, Universitas Pakuan Vol 1. Bogor.

Palupi ER, Dedywiryanto Y. 2008. Kajian karakter toleransi cekaman kekeringan pada empat genotipe bibit kelapa sawit (Elaeis guineensis Jacq). Bul. Agron. 36(1): 24-32.

Prawiranata W, Harran S, Tjondronegoro P. 1988. Dasar-dasar fisiologi tumbuhan. Bogor: Departemen Botani Fakultas Pertanian IPB.

Sarief ES. 1986. Kesuburan dan pemupukan tanah pertanian. Bandung: Pustaka Buana.

Singh CS, Subba-Rao S. 1979. Associative effect of Azospirillum brasilense with Rhizobium japonicum on nodulation and yield of soybean (Glysine max). Plant Soil 53(3): 387-392.

Spaepen S, Vanderleyden J, Remans R. 2007. Indole-3-acetic acid in microbial and microorganism plant signaling. FEMS Microbiol Rev. 31(4): 425-448.

Sylvia D, Fuhrmann J, Hartel P, Zuberer D. 2005. Principles and applications of soil microbiology. New Jersey: Pearson Education Inc. 